\title{
Writing in Political Science: A Brief Guide to Resources*
}

\author{
David Z. Londow, Miami, Florida
}

This bibliography has been compiled for political scientists who may wish to incorporate more writing in their courses or who themselves are engaged in writing projects. That writing is not only a tool to assess student learning or to develop independent critical thinking but a valuable mode of learning in itself is a well-established principle of the "writing-across-the-curriculum" movement. Since writing, like playing the piano, is not a skill which can be learned once and for all in freshman composition, it is, argubly, a "shared responsibility" throughout the liberal arts. Some have even suggested that writing is best taught in the context of particular disciplines.

College teachers are often disappointed with the quality of their students' writing and wonder why English teachers are not doing a better job. Several points, however, need to be kept in mind. First, composition teachers are often graduate students whose real interest is literature, or a seriously underpaid, seriously overworked "underclass" of adjuncts who have too many students in their classes to give each individual sufficient attention.

Second, many writing teachers have a bent for literary or autobiographical writing which they justify on the grounds that students are most interested in themselves and need to develop fluency before they develop competency; however, the writing of students fed a steady diet of personal writing often falls apart in the face of more rigorous argumentative and analytical assignments. Often, the complexity of new material is such that students "forget" what they learned in English class.

Third, in view of the "literacy crisis," many English teachers believe they have more important fish to fry than teach grammar which, anyway, is an "analytical" not a creative tool, does not improve writing, and is best left to a writing center. (By the way, such centers often provide help in other courses besides English, sometimes even with graduate papers and theses.)

And finally, the "literacy crisis" is thought to be political in nature, stemming from unequal access to educational opportunity and requiring "politicized" solutions.

Ironically, therefore, as English teachers begin to occupy the turf of political scientists, we may have to become English teachers. This does not mean that we should teach grammar, but we can hold students accountable for the quality of their writing, not just its content, by, among other things, requiring them to purchase a handbook. Time spent on class or group discussion of student papers in progress is time wellspent. And student-teacher conferences on papers can do much to improve the quality of student writing since hastily scribbled marginal comments are rarely self-explanatory. Above all, students need models of the kinds of writing they are being asked to do; here, past successful student papers are invaluable. If we get back undigested, if not plagiarized, masses of information as term papers, it is because, all too often, we have not taken the time to explain how to construct a political science argument. Above all, revision should be an integral part of the assignment.

And here lies the crux of the matter. If we want our students to write well in political science, we may have to teach them to do so ourselves. If it be argued that such instruction detracts from students' learning political science, we have to ask: what does "learning" mean here?

The books, articles, and chapters listed below contain practical suggestions and theoretical approaches to teaching and using writing in college classrooms. Also included are useful student guides and handbooks. The references to composition and rhetor- ical theory may be of limited interest to political science instructors, but they are provided for those who wish to dabble in this literature. Similarly, it is not expected that a teacher will want to assign a spelling book or ESL grammar. Again, however, instructors may be grateful to know that such books are available to recommend to students or wish to suggest that their bookstores stock them.

Suggestions for additional references may be sent to the author at 10471 S.W. 126th Street, Miami, FL 33176.

\section{Writing in \\ Political Science Courses}

\section{Professional References}

Brodsky, David, and Eileen Meagher. 1987. "Journals and Political Science." In The Journal Book, ed. Toby Fulwiler. Portsmouth, NH: Boynton/Cook.

Brumback, Richard A. 1988. "Teaching Public Administration in a PostLiterate Society." The Political Science Teacher Spring: 1-4.

Cigler, Beverly A. 1990. "Integrated Written and Oral Assignments for the MPA Curriculum."' International Journal of Public Administration 131 (1 and 2): 325-42.

Faigley, Lester, and Kristine Hansen. 1985. "Learning to Write in the Social Sciences." College Composition and Communication 36: 140-49. (a study of the special demands of writing in social science courses)

Goodman, Marshall, and Susan Lanser. 1987. "The Teaching of Writing in Political Science: Defining a Stronger Disciplinary Role." Teaching Political Science: Politics in Perspective 14 (Winter): 60-66.

Hambrick, Ralph S., Jr. 1990. "Incorporating Skill Development into the MPA Curriculum." International Journal of Public Administration 131 (1 and 2): 305-24.

Holland, Kenneth M. 1993. "Briefing the Supreme Court: Summary and Analy- 
sis." In Teaching Critical Thinking: Reports from Across the Curriculum, ed. John H. Clarke and Arthur W. Biddle. Englewood Cliffs, NJ: Prentice-Hall. (a fine guide to helping students learn how to brief Supreme Court cases)

Lazere, Donald. 1992. "Teaching the Political Conflicts: A Rhetorical Schema." College Composition and Communication 43: 194-213. (focuses on the ideological analysis of texts)

Mangel, Nanette V. 1979. "Writing and the Public Administrator: The UNC Experience." Southern Review of Public Administration 3(December): 284-95.

Manns, Edith Kelley, and William L. Waugh. 1986. "Communication in Public Administration: The Need for Skill-Based Education." Proceedings of the Ninth National Conference on Teaching Public Administration (May): 200-08.

Rouse, John, and Laurel Canan. N.d. "Teaching Graduate Education in Public Administration: The Role of Writing Methodology in the Case Method." Muncie, IN: Department of Political Science, Ball State University. (contains very useful criteria for grading course papers)

Stanford, Karen A. 1992. "Disarming the Hunter: Improving Administrative Writing in the Classroom." PS: Political Science \& Politics 25: 696-99.

"Symposium on Writing in Political Science Courses."' 1989. The Political Science Teacher (Summer): 10-17.

\section{Student Texts}

Behrens, Lawrence, and Annabel Nelson, eds. 1992. The American Experience: A Sourcebook for Critical Thinking and Writing. Boston: Allyn and Bacon. (units on Hiroshima, civil rights movement, Vietnam, etc. The entire book may be a valuable supplement in an American Government or Introduction to Political Science course.)

Biddle, Arthur W., and Kenneth M. Holland. 1987. Writer's Guide: Political Science. Lexington, MA: D.C. Heath. (probably the best single book on political science writing)

Fulwiler, Toby, and Arthur W. Biddle, eds. 1992. A Community of Voices: Reading and Writing in the Disciplines. New York: Macmillan. (see ch. 8: Kenneth M. Holland, "The Pursuit of Politics." Highly recommended)

Holland, Kenneth M. 1992. Studying American Government: A Vade Mecum. Lexington, MA: D.C. Heath. (covers study skills as well as writing; useful references)

Kiniry, Malcolm, and Mike Rose, eds.
1993. Critical Strategies for Academic Thinking and Writing, 2nd ed.

Boston: Bedford Books. (see units on neo-colonialism, Cuban Missile Crisis, etc.)

Ravitch, Diane, ed. 1990. The American Reader. New York: Harper Collins.

Ravitch, Diane, ed. 1992. The Democracy Reader. New York: Harper-Collins. (both of the Ravitch volumes are outstanding collections of primary sources)

Williams, James D., David Huntley, and Christine Hanks, eds. 1991. The Interdisciplinary Reader. New York: HarperCollins. (see chapter 6, "Political Science," containing a useful collection of student papers)

\section{Legal Writing}

The Bluebook: Uniform System of Citation. 1991. 15th ed. Cambridge, MA: Harvard Law Review Association.

Gopen, George D., and Kary D. Smout. 1991. "Legal Writing: A Bibliography." Legal Writing 1: 93-112. (comprehensive bibliography, including resources for teaching undergraduate legal writing courses)

Hornstein, Alan D. 1984. Appellate Advocacy. St. Paul, MN: West.

Ray, Mary Bernard, and Barbara J. Cox. 1991. Beyond the Basics: $A$ Text for Advanced Legal Writing. St. Paul: West. (much of the material on writing actual legal documents may be of considerable interest to undergraduates)

\section{Writing for Government}

Bates, Jefferson D. 1990. Writing with Precision, 2nd ed. Washington, DC: Acropolis. (a self-teaching book that wages war against gobbledygook in bureaucratic prose)

Gresham, Stephen L., William Rivers, and John L. Waltman. 1977. Letter Writing for Public Officials. Auburn: Auburn University Office of Public Service and Research. (emphasis on correspondence and reader orientation in government writing)

Masterman, James R., and Wendell Brooks Phillips. 1948. Federal Prose: How to Write in and/for Washington. Chapel Hill: University of North Carolina Press.

Monroe, Judson. 1980. Effective Research and Report Writing in Government. New York: McGraw-Hill.

Redish, Janice C. 1991. How to Write Regulations (and Other Legal Documents) in Plain English. Washington, DC: Document Design Center, American Institutes for Research.

\section{Professional Writing}

Atchity, Kenneth. 1986. A Writer's Time. New York: Norton.

Becker, Howard S. 1986. Writing for Social Scientists: How to Start and Finish Your Thesis, Dissertation, or Book. Chicago: University of Chicago Press.

Boice, Robert. 1989. Professors as Writers. Stillwater, OK: New Forums.

Brusaw, Charles T., Gerald J. Alred, and Walter E. Oliu. 1992. The Handbook of Technical Writing, 4th ed. New York: St. Martin's. (definitive reference for job application letters, resumes, etc.)

Cleveland, W. S. 1985. The Elements of Graphing Data. Monterey, CA: Wadsworth Advanced Books and Software.

Felker, Daniel B. et al. 1981. Guidelines for Document Designers. Washington, DC: Document Design Center, American Institutes for Research.

Kaye, Sanford. 1987. Writing Under Pressure. New York: Oxford University Press.

MacGregor, A. J. 1979. Graphics Simplified. Toronto: University of Toronto Press. (a useful compendium of almost every type of graph and chart)

Martin, Fenton, and Robert Goehlert. 1990. Political Science Journal Information. Washington, DC: American Political Science Association.

Moxley, Joseph. 1992. Publish Not Perish. Westport, CT: Greenwood.

Tufte, Edward R. 1983. The Visual Display of Quantitative Information. Cheshire, CT: Graphics Press. (the acknowledged classic in the field)

Van Leunen, Mary-Claire. 1992. Handbook for Scholars, 2nd ed. New York: Oxford University Press.

Watson, Richard A. 1992. Writing Philosophy: A Guide to Professional Writing and Publishing. Carbondale: Southern Illinois University Press. (covers much more than philosophy)

Wolfinger, Raymond E. 1993. "Tips for Writing Papers." PS: Political Science \& Politics March: 87-88. (advice for graduate students)

“Writing a Dissertation." 1986. PS 19: 61-70. (a symposium)

\section{Style Guides for Scholarly Research}

Chicago Manual of Style. 1982. 13th ed. Chicago: University of Chicago Press. (the definitive reference)

Publication Manual of the American Psychological Association. 1983. 3rd ed. Washington, DC: American Psychological Association.

Style Manual for Political Science. 1988. Washington, DC: American Political Science Association. 


\section{Professional Guides to Usage}

Bernstein, Theodore M. 1977. The Careful Writer. New York: Atheneum.

Follett, Wilson. 1968. Modern American Usage: $A$ Guide, ed. Jacques Barzun. New York: Hill and Wang.

Fowler, H. W. 1965. A Dictionary of Modern English Usage, 2nd ed., rev. Sir Ernest Gowers. New York: Oxford University Press.

\section{Writing as a Mode of Learning}

The works that follow offer the primary theoretical justification for writingacross-the-curriculum: writing is more than a way of demonstrating knowledge acquired; it is, in itself, an important way for students to learn.

Emig, Janet. 1977. "Writing as a Mode of Learning." College Composition and Communication 28: 122-28.

Fulwiler, Toby. 1982. "Writing: An Act of Cognition." In Teaching Writing for All Disciplines, ed. C. Williams Griffin. San Francisco: Jossey-Bass.

Murray, Donald M. 1978. "Internal Revision: A Process of Discovery." In Research on Composing: Points of Departure, ed. Charles R. Cooper and Lee Odell. Urbana: NCTE.

Zinsser, William. 1988. Writing to Learn. New York: Harper Collins.

Writing Across the Curriculum: Theory and Practice

Fulwiler, Toby, and Art Young, eds. 1982. Language Connections. Urbana, IL: National Council of Teachers of English. (useful collection of articles on the different types of writing that can be assigned in disciplinary courses)

Griffin, C. Williams, ed. 1982. Teaching Writing in All Disciplines. San Francisco: Jossey-Bass. (see "Bibliography," pp. 295-319, and Elaine P. Maimon, "Writing Across the Curriculum: Past, Present, and Future.")

Herrington, Anne, and Charles Moran, eds. 1992. Writing, Teaching, and Learning in the Disciplines. New York: Modern Language Association.

Jones, Robert, and Joseph J. Comprone. 1993. "Where Do We Go Next in Writing Across the Curriculum?' College Composition and Communication 44: 59-68. (useful bibliography)

McLeod, Susan, and Margo Soven. 1992. Writing Across the Curriculum: $A$ Guide to Developing Programs. Newbury Park: Sage Publications. (see especially the references on pp. 11, 199-200.)

McCarthy, Lucille. 1987. "Stranger in Strange Lands: A College Student Writing Across the Curriculum." Research in the Teaching of English 21: 233-65.
Russell, David R. 1991. Writing in the Academic Disciplines: A Curricular History. Carbondale, IL: Southern Illinois University Press (see especially ch. 9, "The Writing-Across-theCurriculum Movement: 1970-1990).

Young, Art, and Toby Fulwiler. 1990. "The Enemies of Writing Across the Curriculum." In Programs That Work, ed. Toby Fulwiler and Art Young. Portsmouth: Boynton/Cook.

\section{Faculty Guides to Using Writing}

Barry, Lois. 1984. The Busy Professor's Guide to Writing Across the Curriculum. LaGrande: Eastern Oregon State University Bookstore.

Bogel, Frederic V., and Katherine K. Gottschalk, eds. 1984. Teaching Prose. New York: W.W. Norton. (a remarkably comprehensive text, the basis for Cornell's Freshman Writing Seminars)

Holder, Carol, and Andrew Moss. 1987. Improving Student Writing: A Guidebook for Faculty in All Disciplines. Dubuque: Kendall-Hunt. (an excellent brief guide)

Jolliffe, David. 1993. Writing, Teaching, and Learning: Incorporating Writing Throughout the Curriculum. New York: Harper Collins. (24-minute video that includes political science)

Soven, Margot. 1991. Write to Learn: $A$ Manual for Faculty, 2nd ed. Philadelphia: LaSalle University Writing Project.

\section{Composition Theory}

Bizell, Patricia, and Bruce Herzberg, eds. 1992. The Bedford Bibliography for Teachers of Writing, 3rd ed. Boston: Bedford.

Elbow, Peter. 1973. Writing Without Teachers. New York: Oxford University Press. (one of the cornerstones of the modern "process" view of writing)

Flower, Linda S., and John R. Hayes. 1981. "A Cognitive Process View of Writing." College Composition and Communication 32: 365-87.

Greenblatt, Stephen, and Giles Gunn, eds. 1992. Redrawing the Boundaries. New York: Modern Language Association. (see essays by Richard Marius and Donald McQuade and bibliographies therein.)

Kline, Nancy, ed. 1992. How Writers Teach Writing. Englewood Cliffs: Prentice Hall. (essays form the Expository Writing Program at Harvard)

Perl, Sondra. 1980. "Understanding Composing." College Composition and Communication 31: 363-69. (a phenomenological approach)

\section{Rhetorical Theory}

Arnhart, Larry. 1981. Aristotle on Polit- ical Reasoning. DeKalb: Northern Illinois University Press.

Bizell, Patricia, and Bruce Herzberg, eds. 1990. The Rhetorical Tradition. (an invaluable collection of primary sources)

Booth, Wayne C. 1963. "The Rhetorical Stance." College Composition and Communication 14: 139-45.

Kinneavy, James L. 1971. A Theory of Discourse. New York: W.W. Norton.

Weaver, Richard M. 1953. The Ethics of Rhetoric. Chicago: Regnery.

Young, Richard E., Alton L. Becker, and Kenneth L. Pike. 1970. Rhetoric: Discovery and Change. New York: Harcourt.

\section{Student Rhetorics}

Barzun, Jacques. 1975. Simple and Direct, 2nd ed. New York: Harper and Row. (a marvelous brief text)

Hairston, Maxine C. 1992. Successful Writing, 3rd ed. New York: W.W. Norton. (incorporates the best of modern theory)

Taylor, Gordon. 1989. The Student's Writing Guide for the Arts and Sciences. New York: Cambridge University Press. (highly recommended "writing-across-the-curriculum" textbook; British)

\section{Argument}

Fahnestock, Jeanne, and Marie Secor. 1983. "Teaching Argument: A Theory of Types." College Composition and Communication 34: 20-30.

Kassiola, Joel J. 1992. "Rhetorically Persuasive Writing is Like House Painting: It's All in the Preliminaries." PS: Political Science \& Politics 25: 534-37.

Rogers, Carl R. 1961. "Communication: Its Blocking and Its Facilitation." In Becoming a Person. Boston: Houghton Mifflin. (the classic statement of the view that writers should seek to find "common ground" with their audience)

Toulmin, Stephen. 1958. The Uses of Argument. Cambridge, England: Cambridge University Press. (offers an alternative to deductive and inductive arguments)

Walton, Douglas. 1992. The Place of Emotion in Argument. State College: Penn State University Press.

\section{Student Guides to Argument}

Barnet, Sylvan, and Hugo Bedau. 1993. Critical Thinking, Reading, and Writing. Boston: Bedford Books.

Corbett, Edward P. 1991. The Elements of Reasoning. New York: Macmillan.

Weston, Anthony. 1992. A Rulebook for Arguments, 2nd ed. Indianapolis: Hackett. (highly recommended) 
The Research Paper

Professional Literature

Hyde, Mark, and Robert H. Trudeau. 1973. "Beyond the Traditional Term Paper." Teaching Political Science 1: 94-97.

Morris, J. B., and F. J. Macchiarola. 1970. "Analysis Using Primary Sources for Term Papers in the Introductory Course." PS: Political Science \& Politics 3: 3.

Stotsky, Sandra. 1991. “On Developing Independent Critical Thinking: What We Can Learn from Studies of the Research Process." In Connecting Civic Education and Language Education: The Contemporary Challenge, ed. Sandra Stotsky. New York: Teachers College Press.

\section{Student Texts}

Bazerman, Charles. 1992. The Informed Writer, 4th ed. Boston: Houghton Mifflin. (an outstanding writingacross-the-curriculum text)

Behrens, Lawrence, and Leonard J. Rosen, eds. 1991. Writing and Reading Across the Curriculum, 4th ed. New York: HarperCollins. (the introduction contains useful material on writing summaries, critiques, syntheses, etc.)

Kaufer, David S., Cheryl Geisler, and Christine M. Neuwith. 1989. Arguing from Sources. New York: Harcourt, Brace. (very sophisticated text)

Kennedy, Mary Lynch, and Hadley $\mathbf{M}$. Smith. 1986. Academic Writing: Working with Sources Across the Curriculum. Englewood Cliffs: Prentice Hall. (helps students summarize and synthesize sources; lock-step approach)

Lester, James D. 1993. Writing Research Papers: A Complete Guide, 7th ed. New York: HarperCollins.

Metcalf, Allan A. 1991. Research to the Point. New York: Harcourt, Brace. (excellent brief guide)

O'Hare, Frank, and W. Dean Memering. 1989. The Writer's Work, 3rd ed. Englewood Cliffs: Prentice Hall. (contains useful material on writing summaries, comparisons of two articles, etc.)

Spatt, Brenda. 1990. Writing from Sources, 3rd ed. New York: St. Martin's.

Zimmerman, Donald, and Dawn Rodrigues. 1992. Research and Writing in the Disciplines. New York: Harcourt.

\section{Brief Handbooks and Style Guides} for Students

Cronin, Thomas E. 1993. The Write Stuff, 2nd ed. Englewood Cliffs, NJ: Prentice Hall. (not a grammar guide, but a superb collection of "golden chestnuts" on good writing)

Foley, Stephen Merriam, and Joseph Wayne Gordon. 1986. Conventions and Choices: A Brief Book of Style and Usage. Lexington, MA: D.C. Heath. (an excellent guide for more sophisticated students)

Hacker, Diana. 1992. A Writer's Reference. Boston: Bedford.

Hacker, Diana. 1993. Pocket Style Manual. Boston: Bedford.

Marius, Richard. 1991. A Writer's Companion, 2nd ed. New York: McGrawHill.

Safire, William. 1991. Fumblerules. New York: Dell. (a delightful companion to Strunk and White; covers the most common student errors)

Seeber, Edward D. 1967. A Style Manual for Students, rev. ed. Bloomington, IN: Indiana University Press.

Stone, Wilfred, and Jess G. Bell. 1983. Prose Style, 4th ed. New York: $\mathrm{McGraw}$ Hill. (a very elegant guide for more advanced students)

Strunk, William, Jr., and E. B. White. 1979. The Elements of Style, 3rd ed. New York: Macmillan. (still the classic)

Zinsser, William. 1990. On Writing Well, 4th ed. New York: HarperCollins. (a classic discussion of the contemporary modes of writing, including humor, sports, and so on)

\section{Student Grammar Texts}

Kolln, Martha. 1991. Rhetorical Grammar. New York: Macmillan. (a useful student text that treats grammar less as a means of error avoidance and more as a tool for effective expression)

New Webster's Grammar Guide. 1991. New York: Berkley Books. (covers all the basics)

\section{Revision}

Getting students to revise, not just reword, their papers may be $90 \%$ of teaching them to write.

Flower, Linda. 1979. "Writer-Based Prose: A Cognitive Basis for Problems in Writing." College English 41: 19-37. (students often mistake the order of discovery for a systematic, audience-based, presentation of information.)

Murray, Donald M. 1991. The Craft of Revision. New York: Harcourt. (a useful student text)

Sommers, Nancy. 1980. "Revision Strategies of Student Writers and Experienced Adult Writers." College Composition and Communication 31: 378-88. (an influential theoretical treatment, showing that students often confuse revision with changing a word here or there)
Peer Groups and Collaborative Learning

Bruffee, Kenneth A. 1978. “The Brooklyn Plan: Attaining Intellectual Growth Through Peer-Group Tutoring." Liberal Education 64: 447-69.

Haring-Smith, Tori. 1992. Student Manual for Peer Evaluation. New York: HarperCollins. (a useful collection of forms)

Haring-Smith, Tori. 1993. Learning Together. New York: HarperCollins.

Johnson, David W., Roger T. Johnson, and Edythe Johnson Hulobeo. 1990. Circles of Learning: Cooperation in the Classroom, 3rd ed. Edina, MN: Interaction.

Spear, Karen. 1988. Sharing Writing. Portsmouth, NH: Boynton/Cook. (a stimulating book on the difficulties of getting students to respond usefully to each other's papers)

Trimbur, John. 1989. "Consensus and Difference in Collaborative Learning." College English 51: 602-16.

\section{Student Conferences}

Beach, Richard. 1986. “Demonstrating Techniques for Assessing Writing in the Writing Conference." College Composition and Communication 37: 56-65. (a very useful guide for teachers)

Murray, Donald M. 1979. "The Listening Eye: Reflections on the Writing Conference." College English 41: 13-18. (may be a bit non-directive for some tastes)

\section{Editing: Student Texts}

(See also Fox; and Lane and Lange under "English as a Second Language")

Lanham, Richard. 1987. Revising Prose, 2nd ed. New York: Macmillan. (a very useful brief guide)

Vande Kopple, William. 1989. Clear and Coherent Prose: A Functional Approach. Glenview: Scott Foresman. (a unique approach based on the Prague school of linguistics)

Williams, Joseph M. 1990. Style: Toward Clarity and Grace. Chicago: University of Chicago Press. (perhaps the most sophisticated book of its kind)

\section{College Dictionaries}

The American Heritage Dictionary of the English Language. 1992. 3rd ed. Boston: Houghton Mifflin. (perhaps the most beautiful of all modern dictionaries)

Webster's Ninth New Collegiate Dictionary. 1983. Springfield, IL: MerriamWebster. (the favorite of many teachers for its precision and historically arranged definitions) 


\section{Thesauruses}

Some students suffer from "thesaurusitis": the belief that college teachers like big words and that the big words they don't know mean the same thing as the little words they do know. They resort to a thesaurus as a way to impress rather than to be precise. Newer thesauruses attempt to be more genuinely helpful.

Roget's International Thesaurus, ed.

Robert L. Chapman. 1993. 5th ed.

New York: HarperCollins. (the original smorgasbord)

Roget's II: The New Thesaurus. 1988. Expanded ed. Boston: HoughtonMifflin. (the most precise of all thesauruses: only "true" synonyms are given; furthermore, it is made clear that one word may be synonymous only with a certain meaning of another word)

Webster's Collegiate Thesaurus. 1976. Springfield, IL: Merriam-Webster.

Webster's New Dictionary of Synonyms. 1984. Springfield, IL: MerriamWebster. (this and the preceeding volume discuss shades of meaning in considerable detail with plentiful examples.)

Spelling

Brown, James I., and Thomas E. Pearsall. 1992. Better Spelling, 4th ed. Lexington, MA: D.C. Heath. (a textbook)

Dougherty, M. M. 1990. Instant Spelling Dictionary. New York: Warner.

English as a Second Language

Professional Literature

Guadalupe, Valdes. 1992. "Bilingual Minorities and Language Issues in Education." Written Communication 9: 85-136.

Kaplan, Robert B. 1966. "Cultural Thought Patterns in Inter-Cultural Education." Language Learning 16: 1-12. (the classic discussion of the contrastive rhetoric hypothesis)

Pierpont, Judy. 1991. Second Language Students in the Classroom: A Manual for Instructors. Ithaca, NY: John S. Knight Writing Program, Cornell University.

Tucker, Amy. 1991. Decoding ESL: International Students in the American College Classroom. New York: McGraw-Hill.

\section{Student Texts}

(See also under Basic Writing: Student Texts)

Benson, Morton, Evelyn, and Robert Ilson. 1986. The BBI Combinatory Dictionary of English: A Guide to Word Combinations. Philadelphia: John Benjamin. ("Indispensable ref- erence for students who are learning relatively common English vocabulary items." Pierpont)

Byrd, Patricia, and Beverly Benson. 1992. Applied English Grammar. Boston: Heinle and Heinle. (perhaps the best single volume student guide)

Cobuild English Learners Dictionary. 1989. London: Collins. (useful for "registers" (formal, informal, etc.) of words)

Dictionary of American Idioms. 1987. 2nd ed. New York: Barron's.

Fox, Len. 1991. Focus on Editing. White Plains, NY: Longmans.

Hall, Eugene J. 1982. Dictionary of Prepositions for Students of English. New York: Minerva Books.

Lane, Janet, and Ellen Lange. 1993. Writing Clearly: An Ediiting Guide. Boston: Heinle and Heinle. (excellent text/workbook for ESL students)

Longmans Dictionary of American English. 1983. New York: Longman.

Prepositions I and II. N.d. English Language Services. Boston: Heinle and Heinle. (in the Key to English series)

Raimes, Ann. 1992. Grammar Troublespots. New York: St. Martin's. (a useful student text/workbook on the most common errors)

Basic Writing

Professional Literature

Bartholomae, David. 1985. "Inventing the University." In When a Writer Can't Write: Studies in Writer's Block and Other Composing Process Problems, ed. Mike Rose. New York: Guilford. (a stimulating account of the theory that many students lack adequate socialization into the discourse of the academy)

Rose, Mike. 1989. Lives on the Boundary: The Struggles and Achievements of America's Underprepared. New York: Free Press. (a rich, anecdotal account of what it means to be a "remedial"' student)

Shaughnessy, Mina P. 1977. Errors and Expectations. New York: Oxford University Press. (the classic discussion of the problems of "basic" or "remedial" writers)

\section{Student Texts}

Epes, Mary, Carolyn Kirkpatrick, and Michael G. Sothwell. 1986. The Comp-Lab Exercises: Self-Teaching Exercises for Basic Writing, 2nd ed. Englewood Cliffs, NJ: Prentice Hall.

Fawcett, Susan, and Alvin Sandberg. 1992. Evergreen, 4th ed. Boston: Houghton Mifflin. (student text focusing on paragraphs)

Langan, John. 1992. College Writing Skills, 3rd ed. New York: McGraw-
Hill. (for students who need work on the basic five-paragraph essay)

Williams, Virginia, and Carl David Blake. 1992. Explorations: From Sentence to Paragraph. New York: HarperCollins. (state-of-the-art student text/workbook)

Responding to Student Writing

Lees, Elaine O. 1979. "Evaluating Student Writing." College Composition and Communication 30: 370-74. (actually focuses on techniques of writing marginal comments on student papers)

MacAllister, Joyce. 1982. "Responding to Student Writing." In Teaching Writing for All Disciplines, ed. C. Williams Griffin. San Francisco: Jossey-Bass.

Sommers, Nancy. 1982. "Responding to Student Writing." College Composition and Communication 32: 148-56. (suggests that teachers often produce bad writing by offering contradictory advice)

Evaluation of Student Writing

Conners, Robert J., and Andrea A. Lunsford. 1989. "Frequency of Formal Errors in Current College Writing." College Composition and Communication 39: 95-109. (survey-based catalogue of the most frequent student errors)

Cooper, Charles R., and Lee Odell, eds. 1977. Evaluating Writing. Urbana, IL: National Council of Teachers of English. (discusses such methods as holistic grading and student selfevaluation)

Diedrich, Paul. 1974. Measuring Growth in English. Urbana, IL: National Council of Teachers of English. (the most important theoretical treatment of evaluating student writing)

Williams, Joseph M. 1981. "The Phenomenology of Error." College Composition and Communication 32: 152-65. (suggests that many errors are found only because we look for them)

\section{Note}

${ }^{*}$ My thanks to Tom Cronin, Robert DiYanni, Carol Holder, Ken Holland, Norm Katz, Leonard J. Rosen, and Sandra Stotsky for their generous help.

\section{About the Author}

David Z. Londow has taught political science and public administration at Kalamazoo College and the University of Georgia and most recently at St. Thomas University in Miami. He has also taught writing at the University of Miami and Harvard University. 